\title{
Urban Regeneration and Conservation of Historic Areas in Malaysia
}

\author{
Shahrul Yani Said \\ University Teknologi MARA \\ shahrulyani@salam.uitm.edu.my
}

\begin{abstract}
Heritage cities in the developing nations, including Malaysia, currently face intensified urban problems as a result of rapid population growth, economic development and population growth. The introduction of new townships at the edge of many historic cities in Malaysia has exposed them to severe pressure of commercialization, poor design and cultural uniformity that has faded away their place identity. Thus, regeneration initiatives should be introduced to restore the wealth of the prestigious past of the historic cities and to improve the lifestyle of its population, as the vibrancy of a heritage site is only significant when its original community remains.
\end{abstract}

Keywords: Urban conservation, regeneration, character of place, urban environment

eISSN 2398-4295 @ 2018. The Authors. Published for AMER ABRA cE-Bs by e-International Publishing House, Ltd., UK. This is an open-access article under the CC BY-NC-ND license (http://creativecommons.org/licenses/bync-nd/4.0/). Peer-review under responsibility of AMER (Association of Malaysian Environment-Behaviour Researchers), ABRA (Association of Behavioural Researchers on Asians) and CE-Bs (Centre for EnvironmentBehaviour Studies), Faculty of Architecture, Planning \& Surveying, Universiti Teknologi MARA, Malaysia.

http://dx.doi.org/10.21834/ajbes.v3i11.115 


\subsection{Introduction}

The balance between conservation and redevelopment in developing countries, in general is particularly difficult to maintain (Fitch, 1982:402 in ; Kong and Yeoh, 1994). While the conservation of historic towns and cities in the Western world is considered a common situation, many non-Western countries are still in debate over whether to develop or demolish. In Southeast Asia, particularly in Singapore and Malaysia, the 'conservationdevelopment conflict' or 'conservation dilemma' is further complicated by the plurality of cultures within the cities, all with their own claim to a unique heritage (Kong and Yeoh, 1994). It is important to state that conservation as a process consists of repair, restoration, preservation, maintenance, adaptive reuse and reconstruction.

The main drawback of historic conservation in relation to urban regeneration in Malaysia is the failure of stakeholders to think of conservation as a holistic approach. Conservation is merely based on the restoration and maintenance of individual buildings. The traditional approach of conservation that concentrates on building preservation such as listed buildings will not safeguard the urban heritage and secure the sense of place of the historic cities (Idid, 2005; Shamsuddin and Sulaiman, 2002).

From the perspective of Malaysia, development schemes for historic cities revolves around the idea of introducing new modern development to historic areas, revitalization of the areas and refurbishment of historic buildings, which are often referred to as the tools for the improvement schemes of the cities. Heritage cities in developing nations including Malaysia currently face intensified urban problems as a result of rapid population growth, economic development and urbanization. New townships are seen as a solution to disperse population pressure from city centers and to cater for the growing population. However, new townships at the edge of historic cities were sterile, reflected the adaptation of poor urban design guidelines and hence, failed to create harmony with the historic urban fabric.

Urban design schemes for historic cities in Malaysia involve regeneration or redevelopment, by turning old towns into new by demolishing the old buildings and replacing them with new buildings, and sometimes by adding a new, mixed-use skyscraper on a plot in the middle of the historic center, to demonstrate the regeneration of the area (see Figure 1).

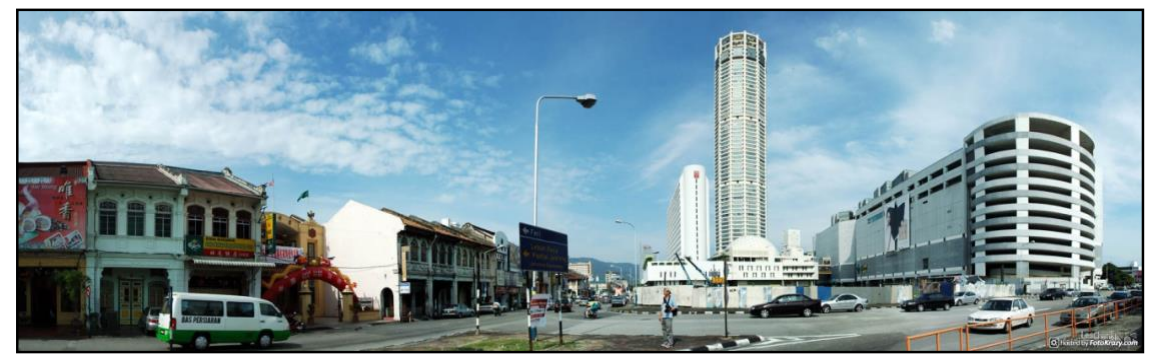

Figure 1: The KOMTAR building (the tallest) and a modern shopping complex on the right side of the photo opposite a row of shop houses in the historic area of George Town Source: Fotokrazy (2007) 
In the context of this study, regeneration refers to: giving back life to the area, by bringing back social, physical and economics activities, while redevelopment refers to any new construction on a site that has pre-existing uses, in the form of urban infill and adaptive reuse. This is the most common approach to regeneration schemes in Malaysia. Urban redevelopment in the form of urban renewal and urban revitalization, however, are carried out in order to regenerate the area.

\subsection{Literature Review}

In Malaysia, urban conservation is classified into three general categories, which are building conservation, area conservation and cultural conservation (Mohamed et al., 2001). The guidelines and policies on urban conservation have been implemented jointly by the local authorities, Federal and State governments, Department of Museums and Antiquity, heritage trusts and other professional bodies. It is fast gaining momentum, and considered as significant to the urban planning and development of the country.

These threats are the result of insensitive redevelopment schemes that were carried out before the introduction of the National Heritage Act 2005. A similar study by Mohamed et al. (2001: p7-p9) carried out in major historic cities in Malaysia such as George Town, Kota Bharu, Melaka, Taiping and Ipoh has identified challenges facing by the heritage cities in Malaysia as:

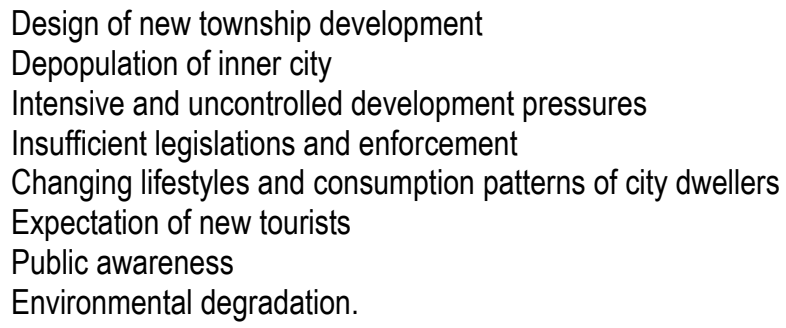

A study of the old town centers in Malaysia commenced in 1992 and revealed some worrying trends that threaten the survival of the historic cities (Shamsuddin and Sulaiman, 2002). The threats are categorized into five groups which are:

The disruption of the urban pattern,

Disappearing townscape,

Changing activity pattern,

Visual monotony and obsolescence

Gentrification

The disruption of the urban pattern increases when the historic core's unique pattern is slowly disrupted by the invasion of office tower blocks and large blocks of shopping complexes altering the existing skyline of the area, as in Penang. Large- scale, modern developments such as hotels and service apartments were introduced in the redevelopment scheme of George Town that could have been located elsewhere if there had been a more appropriate 
development policy that recognized the importance of the unique urban pattern (Figure 2.). Besides, uncontrolled development has resulted in the building of new buildings and facades sandwiched in between old buildings (Wan Ismail, 2012).
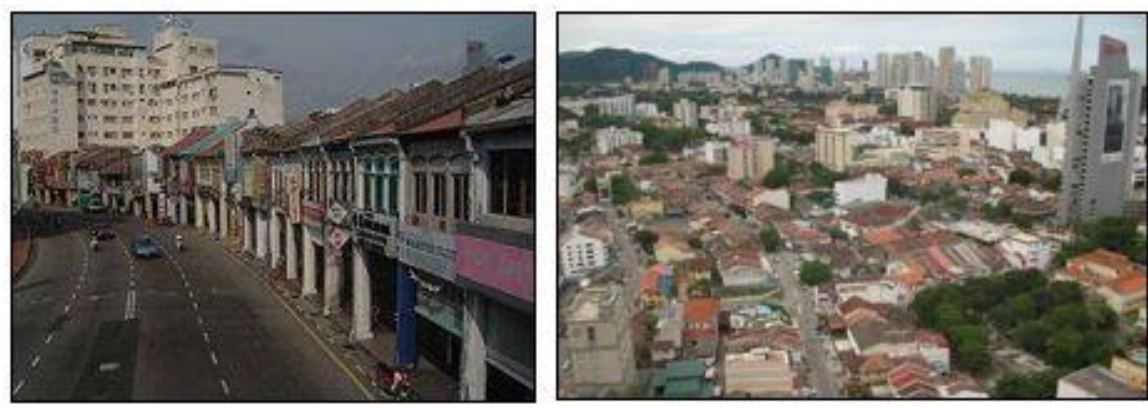

Figure 2. (a) and (b): High rise apartment steal the skyline of George Town WHS Source: Author, 2007

The danger of allowing large scale commercial development, if not designed sensitively within the historic core, might destroy the whole fabric of the historic environment. Such development will only attract insensitive speculative development and inflate the land values. This will make the historic and traditional buildings no longer economically viable and due to the lack of financial abilities often left to dereliction.

The Impact of development

An unsuccessful regeneration approach could also contribute to the disappearance of the unique townscape qualities of the traditional street pattern and their adherence to human scale. Modern commercial development emphasizes large scale and height. The lack of character dominates the area and conceals the rich assets of the traditional buildings, thus eliminating the sense of identity of the place. Nevertheless, new building design could be improved and maintain the character of the traditional shop houses.

Meanwhile, the large scale developments have resulted in the increase of traffic which pressurizes the traditional streets that are not designed to accommodate modern traffic. Therefore, new policies concerning road widening and building setbacks to accommodate the new interventions are introduced. Unfortunately this has altered the historic townscapes. Many of the activities in historic cities such as trading and hawking occur on the streets and the walkways in front of the buildings, creating a sense of place in the city. Inconsiderate regeneration schemes involve the relocation of marketplaces and these traditional stalls to new centralized buildings or areas. The changes to the activity pattern, however, often lead to the death of the historic core when the sense of place is no longer there.

In addition, technological advancement in transportation has decentralized many urban functions from the city and encouraged urban sprawl (Mohamed et al, 2001). In George Town, for example, the younger age-group of the historic city migrated out to find better employment opportunities and to have a better lifestyle. The rise in the value of properties 
has also drawn people away from the area as they could no longer afford the higher market rates.

\subsection{Methodology}

To clarify the current relationship between historic conservation and the planning system in Malaysia, a literature review was undertaken. This was to look at how the policies are implemented and interpreted onto the area and to establish the timeline of conservationrelated legislation in Malaysia. Interviews with local authorities and governmental bodies in Malaysia were conducted to gather such data, as well as sources from national archives. Questionnaire and townscape survey exercise are to be carried out at the later stage in order to gather data on the condition of urban regeneration and conservation of historic areas in Malaysia. The tools for data collection method were designed based on three major urban conservation theme: physical, social and economy (Table 1).

Table 1: Themes used in data collection

\begin{tabular}{|c|c|c|c|c|}
\hline Aim: To examine the relationship between & \multicolumn{4}{|c|}{ Methodologies } \\
\hline THEMES & Interview & $\begin{array}{l}\text { Survey } \\
\text { Questionnaire }\end{array}$ & $\begin{array}{l}\text { Townscape } \\
\text { Survey }\end{array}$ & $\begin{array}{l}\text { Secondar } \\
\text { y data }\end{array}$ \\
\hline $\begin{array}{l}\text { Physical } \\
\text {-building condition } \\
\text {-conservation work } \\
\text {-development composition (old \& new) }\end{array}$ & $\begin{array}{l}v \\
v\end{array}$ & $\begin{array}{l}v \\
v \\
v\end{array}$ & $\begin{array}{l}v \\
y \\
y\end{array}$ & $\begin{array}{l}v \\
v\end{array}$ \\
\hline $\begin{array}{l}\text { Social } \\
\text {-societies' perspectives on conservation } \\
\text {-usage of historic buildings in everyday life } \\
\text {-safety } \\
\text {-cleanliness } \\
\text {-main users of the area }\end{array}$ & $\checkmark$ & $\begin{array}{l}v \\
y \\
y \\
y\end{array}$ & $\begin{array}{l}v \\
v \\
v\end{array}$ & $\checkmark$ \\
\hline $\begin{array}{l}\text { Economy } \\
\text {-reusing historic buildings } \\
\text {-economic state after regeneration }\end{array}$ & $\begin{array}{l}v \\
v\end{array}$ & $\begin{array}{l}y \\
y\end{array}$ & & $\checkmark$ \\
\hline
\end{tabular}

\subsection{Results and Discussions}

Societies live and work in towns and cities and, as they begin to evolve, the urban form does the same to accommodate change and growth. For its users, the city becomes the cultural interpretation of the physical environment through personal identification and attachment. 'Urban heritage is an interpretation of history by a wide range of users; its value, though, is not simply in the historic attributes of the built fabric and spatial aspects of the townscape, but also in the life of the contemporary resident community, differentiating it from other forms 
of heritage' (Orbasli, 2001: p1). Therefore, the aim of urban regeneration must be to enhance the environment and ensure its continuity as a desirable place to live.

In the urban environment, culture and heritage present a question of ownership. While historic buildings are owned individually, the historic town is an entity that is owned communally by the society or community. Urban heritage as a link to history is a combination of tangible aspects (i.e. buildings and streetscape) and intangible aspects (culture, religion, and myths). Therefore, in conserving urban heritage, the considerations of the underlying aspects are significant to ensure the survival of the heritage.

Urban conservation is viewed as the most relevant way to sustain historic cities. To stay relevant and beneficial, historic cities have to catch up with modern, new cities in forms of physical and economic attractions. In order to do so, a good planning method is required to ensure that the historic components will stay intact within the modern environment. One of the best ways to conserve urban heritage is by regeneration.

Regeneration is a growth industry that has influenced the urban planning system of the world today. Regeneration basically is a planning method of renewing, enhancing and integrating the old historic environment to a new, modern, economically thriving environment. It is a process of revitalizing the area of the city that has declined in use and purpose by developing the potential tools such as property, business, retail or arts development in order to enhance the area physically, economically, socially and culturally.

Existing guidelines and implemented schemes of regeneration in Malaysia

The care and conservation of historic buildings in Malaysia are under the jurisdiction of various agencies at different levels. Government agencies, both Federal and State, play important roles in supervising all matters related to conservation and preservation of historic buildings. Besides these agencies, there are a few other public organizations established by groups of architects, planners, journalists, artists and historians, such as the Malaysian Architects Association (PAM) and Malaysian Institute of Planners, to support and maintain the national heritage (Ahmad, 1993).

There are in addition, support groups such as Penang Heritage Trust and the Heritage of Malaysia Trust, which are the two main pressure groups which have been campaigning on the issue of heritage conservation. So far, the pressure groups have created much awareness on the importance of the heritage to the public. Newsletters, heritage awareness campaigns in schools and workshops on conservation were carried out to encourage participation in the protection of heritage in Malaysia.

International corporations, locally based in Malaysia, such as the American Express Foundation had played an active role in promoting historic preservation in Malaysia. For example, in 2002, Georgetown received a grant of US $\$ 80,000$ from The American Express Foundation for the preservation of the city's cultural historic enclaves after being listed in the World's 100 Most Endangered Site by the World Monuments Watch (WMW) of the World Monuments Fund (WMF) based in the USA (Ahmad, 2006). 
Table 2: The roles of federal agencies for the conservation of historic buildings and areas in Malaysia

\begin{tabular}{|c|c|c|}
\hline Ministries & $\begin{array}{l}\text { Department(s) involved in } \\
\text { Conservation }\end{array}$ & Acts, Guidelines and Roles \\
\hline $\begin{array}{l}\text { Ministry of Tourism } \\
\text { and Culture }\end{array}$ & $\begin{array}{l}\text { National Heritage } \\
\text { Department, } \\
\text { responsible for: } \\
\text { World Heritage Sites } \\
\text { Department } \\
\text { Tourism Malaysia }\end{array}$ & $\begin{array}{l}\text { National Heritage Acts } 2005 \\
\text {-Managing; National Heritage Council, National } \\
\text { Heritage Funds, National Heritage Listing } \\
\text {-formation of National Heritage Council as an advisor } \\
\text { for heritage conservation } \\
\text {-Receive and manage the World Heritage Fund } \\
\text {-Funds and tourism promotions }\end{array}$ \\
\hline $\begin{array}{l}\text { Ministry of Urban } \\
\text { Wellbeing and } \\
\text { Federal Territories }\end{array}$ & $\begin{array}{l}\text { Federal Town and } \\
\text { Country Planning } \\
\text { Department }\end{array}$ & $\begin{array}{l}\text { TCPA } 1976 \text { (Act 172) } \\
\text { National Physical Plan (2001) } \\
\text { - a written statement of strategic policies on the } \\
\text { physical development and conservation throughout } \\
\text { the peninsular of Malaysia. The plan was approved by } \\
\text { the National Physical Plan Council on April 26, } 2006 \text {. }\end{array}$ \\
\hline Ministry of Education & Local Universities & Research and training \\
\hline
\end{tabular}

At federal level, four ministries are involved in the protection of national heritage and their roles are described in Table 2. Besides them, at state level, the State Planning Committee (Abel, 1997) plays an important role in monitoring the implementation of the Heritage Management Plan and Act. The functions of this level of the organization are to monitor and liaise between the Federal agency and the local authorities.

Local Authorities such as Kuala Lumpur, Penang, Melaka and Taiping are the front-liners in introducing conservation-based policies to regenerate historic areas in their Special Area Plan. Kuala Lumpur Structure Plan 2020 served as reference for urban development in metropolitan city of Kuala Lumpur, where conservation area identified in this plan are historical and cultural significance buildings and sites.

In Kuala Lumpur Development Control Plan 2008 (KLDCP 2008) several key planning measures that are used to regulate, control and manage physical development of land through development control process and procedures (Kuala Lumpur City Hall ; 2008 ). The KLDCP 2008 conforms to the provisions of the Kuala Lumpur City Plan 2020. Heritage Zone is identified by the City Plan as an area of special architectural or historic interest and character of which it is desirable to preserve or conserve. The purpose of designating such a zone is to ensure that the areas within it maintain the essential historic character or ambience and the development within the area is undertaken with care and sympathy to form, character and scale of existing heritage sites and buildings.

The most recent is the introduction of The Greater Kuala Lumpur/ Klang Valley (GKL/KV) as one (1) of the twelve (12) National Key Economic Areas (NKEA) under the Economic Transformation Programme (ETP). Through Entry Point Project (EPP) 7 : Iconic Places under $\mathrm{GKL} / \mathrm{KV}$, it stated that Greater KL has immense potential to further leverage existing 
heritage sites that can be preserved and redeveloped in a manner that both celebrates the history and heritage, but also embraces a future as a cosmopolitan and global city.

However, the challenge ahead for urban regeneration in Malaysia is to promote development that could help the local communities in the historic cities to continue living their lives in their traditional places, with new revitalized physical settings but without losing their sense of place. New innovative design, through good conservation work, could help in adding value to the buildings and support the needs of modern lifestyles.

Although the idea of individual building conservation is commendable, a shift of the paradigm in urban conservation should be encouraged so that the heritage value of the historic cities is seen in total, and urban heritage conservation should focus on maintaining the sense of place of Malaysia's historic environments. In order to achieve that, public awareness of the importance of safeguarding the historic fabric must be an integral part of the urban conservation processes, alongside the effective role of the stakeholders in the design and enforcement of the policy.

\subsection{Conclusion}

The current policies and guidelines for development of historic cities in Malaysia such as Melaka and George Town have adhered to these measures. According to Mohamed et al. (2001: p10) 'more concerted efforts are needed to navigate problems experienced in the heritage cities, which should be geared at various levels'. More transparent local initiatives, provision of grants and technical advice, sufficient law and enforcement, the introduction of sustainable measures in planning and heritage partnerships are the measures to be improved in the Malaysian context. In response to the problems faced by historic cities in Malaysia, the local authorities of the five heritage cities have undertaken various initiatives and measures in dealing with the challenges. Among the measures and initiative taken are:

- Zoning of conservation and buffer zone

- Pedestrianisation in heritage cities

- Diversification of tourism products

- Heritage and tourism management

- Local involvement in Heritage Conservation

Besides that, a good funding mechanism for conservation schemes in Malaysia should be introduced in order to ensure the sustainability of the schemes. Malaysia could learn from the UK and European approach on funding mechanism for heritage-led regeneration scheme by introducing partnership in the projects, which currently not being in practiced in the Country. The successful partnership in the Grainger Town Project for example, shows the cooperation between public and private sectors to support regeneration for the area that could benefit all parties in as a long-term investment.

According to Pickard (2009: p13), governments can encourage conservation, restoration and rehabilitation process in two ways: 'the first involves policies and measures to stimulate 208 
the private sector to invest in architectural heritage (the dynamic approach). The second derives from the fact that, without government support, the private sector may decide that investment is not economically justified, thus creating the need for financial incentives and subsidies (the support approach)'. Pickards (2009: p14) also explained that evidence from heritage-led regeneration scheme suggests that partnership programs can generate six time or more of the initial public investment through the private sector partners or other sources. Thus, partnership scheme should be introduced and considered in urban conservation and regeneration projects in Malaysia, to guarantee commitments from the public and private sectors in sustaining their built heritage.

It is recommended for the future, that a study on the social characteristics of the area should be carried out in the initial stage before deciding on the choice of a data collection method in order to avoid the issue of poor cooperation from the local respondents. Further research on the conservation of historic cities in Malaysia is recommend to focus on the policy and public involvement in conservation and the regeneration of historic areas. The need to involve the public with decision making on the future of their cities is important, as the locals are the end-users to every regeneration scheme, and therefore are the group responsible for ensuring the sustainability of their area. Development according to their decisions will make them appreciate the place more.

\section{Acknowledgement}

The authors would like to acknowledge Ministry of Higher Education (MOHE) and Universiti Teknologi Malaysia for facilitating the research. This research is carried out under Research Acculturation Grant Scheme (RAGS175/2013).

\section{References}

Abel, C. (1997). Architecture and identity: Towards a global eco-culture. Oxford: Architectural Press.

Ahmad, A. G. (1993). Conservation of british colonial buildings built between 1800 and 1930 in Malaysia. PhD. University of Sheffield.

Ahmad, A. G. (1998). Urban tourism in Malaysia: Heritage cities of Georgetown, Malacca and Kota Bahru. In: International Seminar on European Architecture and Town Planning Outside Europe (Dutch Period).

Ahmad, A. G. (2006). Cultural Heritage of South East Asia: Preservation for World Recognition. Journal of Malaysian Town Plan, 3(1), 52-62.

Bianchini, F. \& Parkinson, M. E. (1993). Cultural policy and urban regeneration: The West European experience. Cities, 12(4).

Earl, J. (2003). Building conservation philosophy. 3rd ed. UK: Donhead.

Fielden, B. M. (2003). Conservation of historic buildings. 3rd ed. Oxford: Elsevier. 
Said, S.Y. / Asian Journal of Behavioural Studies (AjBeS), 3(11) May / Jun 2018 (p. 201-210)

Fotocrazy (2007). My view of Penang in panorama. In: Penang Remembered 2007, ed. Nikon D70.

Idid, S. Z. A. (1996). Pemeliharaan warisan rupa bandar Kuala Lumpur: Badan Warisan Malaysia.

Idid, S. Z. A. (2005). Urban conservation approach for a multi cultural historic cities: The urban planning and design perspective: case study, Historic City of Malacca. Department of Urban Engineering, University of Tokyo.

Kong, L. \& Yeoh, B. (1994). Urban conservation in Singapore: A survey of state policies and popular attitudes. Urban Studies, 1(2).

Melaka. Majlis Bandaraya Melaka Bersejarah (2010). Special Area Plan: Conservation area management plan of Melaka Historical City. Melaka: Majlis Bandaraya Melaka Bersejarah.

Mohamed, B., Ahmad, A. G. \& Badarulzaman, N. (2001). Challenges of Historic Cities in the New Millennium: Lessons from Malaysia. In: International Symposium on Future Cities. Riyadh, Saudi Arabia.

Orbasli, A. (2001). Tourists in historic towns: Urban conservation and heritage management. England: Taylor \& Francis.

Orbasli, A. (2008). Architectural conservation. Oxford: Blackwell.

Penang. State Government (2008). Heritage management plan. George Town.

Pickard, R. (2009). Funding the architectural heritage: A guide to policies and examples. Strasbourg Cedex: Council of Europe Publishing.

Said, S. Y. (2007). Modern development in historic cities: The case study of the Historic City of Malacca. York: University of York.

Shamsuddin, S. \& Sulaiman, A. B. (2002). The Importance of Conserving the Old Town Centre in Achieving a Sustainable Built Environment of the Future. In: National Seminar on Built Environment: Sustainability through Management and Technology.

Uda Holdings Berhad (2008). Introduction. Available at: www.udaholdings.com.my. 